\begin{tabular}{|c|c|c|}
\hline & Int.J.Curr.Microbiol.App.Sci (2021) 10(09): 327-332 & \multirow{4}{*}{ 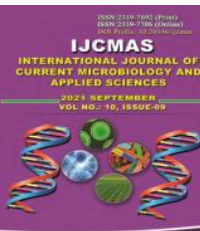 } \\
\hline & International Journal of Current Microbiology and Applied Sciences & \\
\hline & ISSN: 2319-7706 Volume 10 Number 09 (2021) & \\
\hline $\begin{array}{l}\text { EXCELLENT } \\
\text { PUBLISHERS }\end{array}$ & Journal nomepage: nup://www.1]cmas.com & \\
\hline
\end{tabular}

\title{
Diversity of Insect Pests and Ecofriendly Fauna Inhabiting Chickpea (Cicer arietinum L.) Agro-Ecosystem in Bundelkhand Region of Uttar Pradesh
}

\author{
Hari Prakash Namdev* and Ram Subhag Singh
}

Department of Agriculture Entomology, Brahmanand Post Graduate College,
Rath, Hamirpur, Uttar Pradesh - 210431, India

*Corresponding author

Keywords

Chickpea, diversity, insect pests, ecofriendly fauna

Article Info

\section{Accepted:}

15 August 2021

Available Online:

10 September 2021
A B S T R A C T

An experiment was conducted at Agricultural Research Farm of Brahmanand Post Graduate College, Rath, Hamirpur (U.P.) during 2016-17 and 2019-20 cropping season. In the Bundelkhand agro climatic region seventeen species of insect belonging to seven orders and twelve families were recorded from chickpea agro ecosystem. Among which six species from Lepidoptera, four species from hymenoptera, two species from coleoptera and odonata and one species from hemiptera, isoptera, and dyctyoptera were identified. On the basis of economic importance nine species were insect pests, five species were predators, two species were insect parasitoids and one species was insect pollinator. Among the nine species of insect pests, chickpea pod borer, Helicoverpa armigera Hub. and gram cut worm, Agrotis ipsilon (Huf.) occurred regularly and chickpea pod borer was designated as a major pest while, gram cut worm infested with very low population density and considered as minor insect pest of chickpea. The five species of insect pest occurred occasionally i.e. armyworm, Mythmina separate (walker), tobacco caterpillar, Spodoptera litura (Fab), cow pea aphid, Aphis craccivora (Koch), termite, Odentotermes obesus (Rambur) and black flea beetle, Altica Species (unidentified species) were designated as minor pest of chickpea. While, two species namely, Bihar hairy caterpillar, Spilarctia obliqua (Walker) and beet armyworm, Spodoptera oxiqua (Hub) occurred intermittently in sporadic manner and designated as stray pest of chickpea. The eight species of insect's ecofriendly fauna inhabiting chickpea agro ecosystem were observed, among which five species of predators, two species of parasitoids and one species of pollinators foraged on chickpea crop occasionally in very low population density. The maximum number of ecofriendly fauna was of the order hymenoptera, two species of parasitoids, one species of predators and pollinator i.e. Trichogrammatid wasp, Trichogramma chilonis (Ishii), ichneumonid wasp, Campoletis chloridae (Uchida), common yellow wasp, Vespa oreintalis (L.) and small honeybee, Apis floraea followed by odonata i.e. dragonfly, Croccothemis servielia (Drury) and damsel fly, Agriocnemis pygmiea (Rambur), coleoptera, rove beetle, Alleochara billienata and dyctyoptera, praying mantis, Mantis religiosa (L.). 


\section{Introduction}

Chickpea (Cicer arietinum L.) is the most important pulse crop of India. But in the world India is the premier producer of chickpea by holding $90 \%$ of world production. In India, chickpea is grown generally in all the states but M.P., U.P. and Rajasthan has contributed maximum area 23\%, $18 \%$ and $11 \%$ respectively under chickpea cultivation. In India, total area under chickpea cultivation is 10.2 million hectare with an annual production of 8.37 million tones and $935 \mathrm{~kg} / \mathrm{hec}$ average productivity (Anonymous, 2020).

Chickpea is attacked by more than 25 species of insects and of them gram pod borer (Helicoverpa armigera Hub.) and gram cut worm, Agrotis ipsilon (Hub) are major importance of national significance and six insect pest i.e. bean aphid, Aphis craccivora, (Koch) semilooper, Autographa nigrisigna, (Walker), tobacco caterpillar, Spodoptera exigua (Hub) pod bug, Riptortus pedestris (Fab) and leaf Webber, Eucosma critica are major pest of regional significance (Sharma et al., 2020).

Chickpea pod borer is a polyphagous insect pest of pulses and widely distributed in the world. In India, it has been observed to feed on 181 cultivated and uncultivated species belonging to 45 families. Thus, keeping these facts in view, an effort was made to record the diversity of insect fauna inhabiting the chickpea agro ecosystem in Bundelkhand agro-climatic region of Uttar Pradesh.

\section{Materials and Methods}

An experiment was conducted at Agricultural Research Farm of Brahmanand Post Graduate College, Rath, Hamirpur (U.P.) during 201617 and 2019-20 cropping season. The appearance of insect pests and ecofriendly fauna including predators and parasitoids inhabiting chickpea agro-ecosystem were observed at weekly intervals from the seedling stage of chickpea to the maturing of the crop.

The chickpea cultivar Radhey was sown in the plot size of $5 \times 3$ meter during the second fortnight of October 2016-17 and 2019-20 cropping season. The incidence of insect pests and ecofriendly fauna were observed visually at weekly intervals throughout cropping season.

The qualitative diversity of insect pests and ecofriendly fauna were categorized in to different groups on the basis of their occurrence. The insect-pest and ecofriendly fauna which infested the crop continuously after their first appearance in considerable number were designated as major and those which occurred intermittently and their population never become high were categorized as minor, while the species whose occurrence were scares with very low population shall be designated as stray.

\section{Results and Discussion}

A list of various insect pests and ecofriendly fauna inhabiting chickpea agro ecosystem in Bundelkhand agro-climatic zone during 201617 and 2019-20 cropping season is presented in Table 1. The seventeen species of insect fauna of different groups were observed form chickpea agro ecosystem during both the cropping season.

The diversity of insect fauna were categorized in different groups i.e. pest, predator, parasitoid and pollinator on the basis of their feeding behavior. On the basis of occurrence, these insect pest and beneficial insect occurred on the crop continuously after their first appearance and in considerable numbers were designated as regular occurrence, while those insect fauna whose population occurred intermittently or otherwise disappear before 
harvest were categorized as sporadic or occasional occurrence. The insect fauna which were merely recorded and whose population occurred after a considerable time lag were designated as stray.

The perusal of qualitative diversity of insect fauna inhabiting chickpea agro ecosystem from table revealed that 17 species belonging to 7 orders and 12 families were recorded throughout the cropping period of chickpea during 2016-17 and 2019-20.

Based on number of species collected, the largest collection was represented by order lepidoptera (06 species) followed by orders hymenoptera (04 species), coleoptera and odonata (02 species of each order) and hemiptera, isoptera and dictyoptera (01 species of each order).

On the basis of economic importance the faunal diversity of insects were observed as insect-pests (09 species), insect predators (05 species), insect parasitoids (02 species) and insect pollinator (01 species) from chickpea cropping system in Bundelkhand agro climatic zone of Hamirpur (U.P.).

Chickpea is infested by 25 species. all insects among which three i.e. gram pod borer (Helicoverpa armigera Hub.), Cut worm (Agrotis ipsilon Huf.) and termite (Odentotermes obesus Ramb.) insect pests are major importance of national significance and 6 insect pests i.e. bean aphid (Aphis craccivora Koch.), semilooper (Autographa nigrisigna Walker.), tobacco caterpillar (Spodoptera exigua Hub.), pod bug (Riptortus pedertris) and leaf webber (Eucosoma critica) are major pests of regional significance (Sharma et al., 2020).

Among the nine species of insect-pests two species were designated as regular in occurrence i.e. chickpea pod borer,
Helicoverpa armigera (Hub.) (Lepidoptera: Noctuidae) and gram cut worm, Argotis ipsilon (Hufnagel) and five species were designated to occurred occasionally i.e. army worm, Mythimna seperata (Walker) (Lepidoptera: Noctuidae), tobacco caterpillar, Spodoptera litura (Fab.) (Lepidoptera: Noctuidae), cowpea aphid, Aphis craccivora (Koch) (Hemiptera: Aphididae), termite, Odentotermes obesus (Rambur) (Isoptera:Termitidae) and black flea beetle, Altica species (undentified species) (coleoptera:chrysomelidae) and identified as minor pest of chickpea. While, two species namely, Bihar hairy caterpillar, Spilarctia obliqua (walker) (Lepidoptera:Noctuidae) and beet army worm, Spodoptera exigua (Hub) (Lepidoptera: Noctuidae) occurred intermittently in sporadic manner and designated as stray pest of chickpea.

Among two regular pests the gram pod borer (H. armigera) was noticed as major insect pest of chickpea which infested both vegetative and reproductive growth phase of chickpea crop, while gram cut worm (Agrotis ipsilon) occurred regularly on chickpea (vegetative and reproductive stage) with very low population density and considered as minor insect pest of chickpea. However, a previous study conducted by Singh et al.,(2018), Sharma et al., (2020) and Ramveer et al., (2021) observed that chickpea pod borer (Helicoverpa armigera) and gram cut worm (Agrotis ipsilon) are major pests of chickpea in Uttar Pradesh and Madhya Pradesh.

The qualitative diversity of ecofriendly insect fauna (predators, parasitoids and pollinators) inhabiting chickpea agro-ecosystem (Table 1) revealed that eight species of insects (05 species of predators, 02 species of parasitoids and one species of pollinator) were observed to forage chickpea crop occasionally in very low population density and designated as minor ecofriendly fauna. 
Table.1 Qualitative diversity of insect pests and ecofriendly fauna inhabiting chickpea (Cicer arietinum L.) agro ecosystem

\begin{tabular}{|c|c|c|c|c|c|c|c|c|c|}
\hline \multirow[t]{2}{*}{ S.No. } & \multirow[t]{2}{*}{ Common Name } & \multirow{2}{*}{$\begin{array}{l}\text { Scientific } \\
\text { Name }\end{array}$} & \multirow{2}{*}{$\begin{array}{l}\text { Order: } \\
\text { Family }\end{array}$} & \multicolumn{2}{|c|}{ Occurrence } & \multicolumn{2}{|c|}{ Status } & \multirow[t]{2}{*}{ Crop Stage } & \multirow[t]{2}{*}{ Nature } \\
\hline & & & & $2016-17$ & 2019-20 & $2016-17$ & $2019-20$ & & \\
\hline 1 & Gram pod borer & $\begin{array}{c}\text { Helicoverpa } \\
\text { armigera } \\
\text { (Hub.) }\end{array}$ & $\begin{array}{l}\text { Lepidoptera: } \\
\text { Noctuidae }\end{array}$ & Regular & Regular & Major & Major & $\begin{array}{l}\text { Vegetative \& } \\
\text { reproductive } \\
\text { stage }\end{array}$ & Pest \\
\hline 2 & Gram cut worm & $\begin{array}{l}\text { Agrotis ipsilon } \\
\text { (Hufnagel) }\end{array}$ & $\begin{array}{l}\text { Lepidoptera: } \\
\text { Noctuidae }\end{array}$ & Regular & Regular & Minor & Minor & $\begin{array}{l}\text { Vegetative } \\
\text { stage }\end{array}$ & Pest \\
\hline 3 & Army worm & $\begin{array}{c}\text { Mythimna } \\
\text { seprata } \\
\text { (Walker) }\end{array}$ & $\begin{array}{l}\text { Lepidoptera: } \\
\text { Noctuidae }\end{array}$ & Occasional & Occasional & Minor & Minor & $\begin{array}{l}\text { Vegetative } \\
\text { stage }\end{array}$ & Pest \\
\hline 4 & $\begin{array}{l}\text { Tobacco } \\
\text { caterpillar }\end{array}$ & $\begin{array}{c}\text { Spodoptera } \\
\text { litura } \\
\text { (Fabricius) }\end{array}$ & $\begin{array}{l}\text { Lepidoptera: } \\
\text { Noctuidae }\end{array}$ & Occasional & Occasional & Minor & Minor & $\begin{array}{l}\text { Vegetative } \\
\text { stage }\end{array}$ & Pest \\
\hline 5 & $\begin{array}{l}\text { Bihar hairy } \\
\text { caterpillar }\end{array}$ & $\begin{array}{l}\text { Spilorctia } \\
\text { oblique } \\
\text { (Walker) }\end{array}$ & $\begin{array}{l}\text { Lepidoptera: } \\
\text { Arctiidae }\end{array}$ & Sporadic & - & Stray & - & $\begin{array}{l}\text { Vegetative } \\
\text { stage }\end{array}$ & Pest \\
\hline 6 & Beet armyworm & $\begin{array}{c}\text { Spodoptera } \\
\text { exigua (Hub.) }\end{array}$ & $\begin{array}{l}\text { Lepidoptera: } \\
\text { Noctuidae }\end{array}$ & Sporadic & Sporadic & Stray & Stray & $\begin{array}{l}\text { Vegetative } \\
\text { stage }\end{array}$ & Pest \\
\hline 7 & Cowpea aphid & $\begin{array}{l}\text { Aphis } \\
\text { craccivora } \\
\text { (Koch) }\end{array}$ & $\begin{array}{l}\text { Hemiptera: } \\
\text { Aphididae }\end{array}$ & Occasional & Occasional & Minor & Minor & $\begin{array}{l}\text { Vegetative \& } \\
\text { reproductive } \\
\text { stage }\end{array}$ & Pest \\
\hline 8 & Termite & $\begin{array}{c}\text { Odentotermes } \\
\text { obesus } \\
\text { (Rambur) }\end{array}$ & $\begin{array}{l}\text { Isoptera: } \\
\text { Termitidae }\end{array}$ & Occasional & Occasional & Minor & Minor & $\begin{array}{l}\text { Vegetative \& } \\
\text { reproductive } \\
\text { stage }\end{array}$ & Pest \\
\hline 9 & Black flea beetle & Altica sp. & $\begin{array}{l}\text { Coleoptera: } \\
\text { Chrysomelidae }\end{array}$ & Occasional & Occasional & Minor & Minor & $\begin{array}{l}\text { Vegetative } \\
\text { stage }\end{array}$ & Pest \\
\hline 10 & Dragonfly & $\begin{array}{l}\text { Crocothemis } \\
\text { servilia } \\
\text { (Drury) }\end{array}$ & $\begin{array}{l}\text { Odonata: } \\
\text { Libellulidae }\end{array}$ & Occasional & Occasional & Minor & Minor & $\begin{array}{l}\text { Vegetative \& } \\
\text { reproductive } \\
\text { stage }\end{array}$ & Predator \\
\hline
\end{tabular}




\begin{tabular}{|c|c|c|c|c|c|c|c|c|c|}
\hline 11 & $\begin{array}{c}\text { Common yellow } \\
\text { wasp }\end{array}$ & $\begin{array}{c}\text { Vespa } \\
\text { orientalis (L.) }\end{array}$ & $\begin{array}{l}\text { Hymenoptera: } \\
\text { Vespidae }\end{array}$ & Occasional & Occasional & Minor & Minor & $\begin{array}{l}\text { reproductive } \\
\text { stage }\end{array}$ & Predator \\
\hline 12 & Small honey bee & Apis florea & $\begin{array}{l}\text { Hymenoptera: } \\
\text { Apidae }\end{array}$ & Occasional & Occasional & Minor & Minor & $\begin{array}{l}\text { Flowering } \\
\text { stage }\end{array}$ & Pollinator \\
\hline 13 & Rove beetle & $\begin{array}{c}\text { Aleochara } \\
\text { billineata }\end{array}$ & $\begin{array}{l}\text { Coleoptera: } \\
\text { Staphylinidae }\end{array}$ & Occasional & Occasional & Minor & Minor & $\begin{array}{l}\text { Vegetative \& } \\
\text { reproductive } \\
\text { stage }\end{array}$ & Predator \\
\hline 14 & $\begin{array}{c}\text { Trichogrammatid } \\
\text { wasp }\end{array}$ & $\begin{array}{l}\text { Trichogramma } \\
\text { chilonis (Ishii) }\end{array}$ & $\begin{array}{l}\text { Hymenoptera: } \\
\text { Trichogrammatidae }\end{array}$ & Occasional & Occasional & Minor & Minor & $\begin{array}{l}\text { reproductive } \\
\text { stage }\end{array}$ & Parasitoid \\
\hline 15 & $\begin{array}{l}\text { Ichneumonid } \\
\text { wasp }\end{array}$ & $\begin{array}{c}\text { Campoletis } \\
\text { chloridae } \\
\text { (Uchida) }\end{array}$ & $\begin{array}{l}\text { Hymenoptera: } \\
\text { Ichneumonidae }\end{array}$ & Occasional & Occasional & Minor & Minor & $\begin{array}{l}\text { reproductive } \\
\text { stage }\end{array}$ & Parasitoid \\
\hline 16 & Preying mantis & $\begin{array}{c}\text { Mantis } \\
\text { religiosa }(\mathrm{L} .)\end{array}$ & $\begin{array}{l}\text { Dictyoptera: } \\
\text { Mantidae }\end{array}$ & Occasional & Occasional & Minor & Minor & $\begin{array}{l}\text { Vegetative \& } \\
\text { reproductive } \\
\text { stage }\end{array}$ & Predator \\
\hline 17 & Damsel fly & $\begin{array}{c}\text { Agriocnemis } \\
\text { pygmaea } \\
\text { (Rambur) }\end{array}$ & $\begin{array}{l}\text { Odonata: } \\
\text { Agrionidae }\end{array}$ & Occasional & Occasional & Minor & Minor & $\begin{array}{l}\text { Vegetative \& } \\
\text { reproductive } \\
\text { stage }\end{array}$ & Predator \\
\hline
\end{tabular}


The maximum number of ecofriendly fauna was of the order Hymenoptera (2 species of parasitoid, 1 species of predator and pollinator) i.e. trichogrammatid wasp, Trichogramma chilonis (Ishii) (Hymenoptera: Trichogrammatidae), ichneumonid wasp Campoletis chloridae (Uchida) (Hymenoptera : Ichneumonidae) common yellow wasp and small honey bee followed by Odonata i.e. dragonfly, Crocothemis servilila (Drury) (Odonata : Libelullidae) and damsel fly, Agriocnemis pygmaea (Rambur) (Odonata: Agrionidae), Coleoptera, rove beetle, Alleochara billineata (Coleoptera: Staphylinidae) and Dictyoptera, praying mantis, Mantis religiosa (L.) (Dictyoptera:Mantidae). The findings is in accordance with the observation made by Singh et al.,(2018) who reported that Campoletis chloridae and Trichogramma chilonis occurred predominantly in chickpea ecosystem at Kanpur Uttar Pradesh.

\section{Acknowledgement}

The research paper is part of $\mathrm{Ph} . \mathrm{D}$ thesis of Hari Prakash Namdev. The author is greatful to Principal B.N.P.G.College, Rath, Hamirpur (U.P.) for providing of Laboratory, Library and research field facilities. The author also oblige to Ph.D. research cell of Bundelkhand University, Jhansi for their valuable support and guidance.

\section{References}

Anonymous (2020) General Survey of Agriculture: Agricultural Situation in India, LXXVI (12):pp1-12.

Ramveer, Chandra U, Gautam, C. P. N., Yadav, S. K., Sharma, S., kumar S, and Akshay kumar.(2021) Study on incidence of insect pests in chickpea. Journal of Entomology and Zoology Studies. 9(1):146-150.

Sharma, A. K., Mandloi, R., Saxena, A. K., Thakur, A. S., Sharma, R. and Ramakrishnan, R. S.(2020) Biodiversity of Phototactic insect pests of chickpea ecosystem and records on population dynamics of Helicoverpa armigera (Hubner) And Agrotis ipsilon (Hufnagel).Journal of Pharmacognosy and Phytochemistry, 9(1):824-829.

Singh, V. V., Agarwal, N., Satish, B. N., Kumar S, Kumar S and Krishan Pal.(2018) Studies on insect diversity in chickpea (Cicer arietinum Linnaeus) ecosystem. Journal of Entomology and Zoology Studies, 6(5):693-697.

\section{How to cite this article:}

Hari Prakash Namdev and Ram Subhag Singh. 2021. Diversity of Insect Pests and Ecofriendly Fauna Inhabiting Chickpea (Cicer arietinum L.) Agro-Ecosystem in Bundelkhand Region of Uttar Pradesh. Int.J.Curr.Microbiol.App.Sci. 10(09): 327-332. doi: https://doi.org/10.20546/ijcmas.2021.1009.038 